\title{
TESTING ON THREE DETERMINING METHODS OF GENETIC DIVERSITY ON EARTHWORM SPECIES BELONGING TO THE PHERETIMA SPECIES GROUP IN THE MEKONG DELTA
}

\author{
Nguyen Thanh Tung*, Tran Nhan Dung, Pham Minh Tu \\ Can Tho University, ${ }^{(*)}$ thanhtung@ ctu.edu.vn
}

\begin{abstract}
This paper introduced the testing results of three methods (analysis of morphological characteristics using numerical phenetics, the whole-cell proteins using SDS-PAGE and the DNA barcode sequences) used for determination of the genetic diversity of some earthworm species belonging to the Pheretima species group in the Mekong Delta (Amynthas paraalexandri, A. juliani, Metaphire posthuma, M. bahli, M. peguana, M. houlleti, Metaphire sp.8, Polypheretima elongata and $P$. taprobanae). All three methods yielded compatible and reliable results which appropriately explained the genetic relationships between closely related species and those between taxa of high taxonomic levels (families, genera). Phylogenetic tree constructed on the basis of DNA barcode analysis was able to indicate clearly genetic divergence between Pheretima species belonging to acoecata and coecata. Metaphire sp.8 was demonstrated to be a closely related species with M. houlleti.
\end{abstract}

Key words: DNA barcode, earthworm, phenetics, Pheretima, SDS-PAGE, Me Kong Delta.

\section{INTRODUCTION}

Genetic diversity, the level of biodiversity, refers to the total number of genetic characteristics in the genetic makeup of a species. Depending on different stages of development of the biological science, determining methods of genetic diversity has changed and evolved over time. As the Pheretima species groups contain a large number of species, species division and classification into smaller genera are necessary, but the amendment process for these species was based only on morphological markers $[4,11,14,18]$. DNA barcode (a gene segment of mitochondrial Cytochrome C Oxidase subunit I) was considered as a useful molecular marker that might be able to determine the genetic relationships between earthworm species $[3,9,10,15]$. In this study, the whole-cell protein eletrophoretic analysis using SDS-PAGE was also tested to examine the genetic relationships between different species.

This study could provide a basis to improve the current classification system of the Pheretima species group in Vietnam and even possible, in the world.

\section{MATERIALS AND METHODS}

\section{Samples}

Pairs of closely related earthworm species Amynthas paraalexandri (Nguyen, 2011),
A. juliani (Perrier, 1872), Metaphire posthuma (Vaillant, 1868), M. bahli (Gates, 1945), M. peguana (Rosa, 1889), M. houlleti (Perrier, 1872), Metaphire sp. $8=$ Pheretima campanulata (Thai, 2000), Polypheretima elongata (Perrier, 1872) and P. taprobanae (Beddard, 1892) were collected in many different localities in the Mekong Delta. Adult earthworms were stored in 4\% formalin solution for morphological analysis and in $96 \%$ ethanol for DNA extraction while the alive earthworms were used for extraction of whole-cell proteins.

Scientific name of species used follow the classification system of Sims and Easton (1972) [18]. In addition, Pontodrilus litoralis and Pontoscolex corethrurus were used for morphological analysis and DNA barcodes of 10 species obtained from the GeneBank were used for molecular analysis.

\section{Methods}

Morphologial analysis with numerical phenetics: the construction of a phylogenetic tree with numerical phenetics was based on morphology as described below: Determining the important morphological characteristics of the studied earthworms (table 1) based on previous studies of Thai Tran Bai (1986), Easton (1979), Ishizuka (1999), Sims and Easton (1972) [1, 11, 13, 18]. Identifying the 
important morphological characteristics that are valuable in the classification of earthworms. For the highly variable traits, those with the highest probability of existence among individuals within species were analyzed, while the multistate traits were divided into groups. The common characteristics of selected studied species were recorded. The traits of all species were encoded into a binary matrix. Genetic similarity was measured by Dice's/Nei and Li's coefficients. The similarity matrix was subjected to cluster analysis by unweighted pair group method for arithmetic mean (UPGMA). The dendrogram was generated using the program NTSYS-PC 2.1 with clustering algorithms SAHN (Sequential, Agglomerative, Hierarchical, and Nested clustering methods). Support for clusters was evaluated by bootstrapping analysis with 1000 bootstrap replicates by using FreeTree software.

Table 1. Traits and morphological characteristics that were used to determine the genetic diversity of earthworm species

\begin{tabular}{|c|c|c|}
\hline No. & Morphological characteristic & Trait \\
\hline 1 & Size body & 1: small; 2: medium; 3: large \\
\hline 2 & The colour of body between ventral and dorsal & 4: similar; 5: different \\
\hline 3 & Prostomium & 6: Epi; 7: Pro \\
\hline 4 & The first dorsal pore & 8: absent; 9 : in $11 / 12 ; 10$ : in $12 / 13$ \\
\hline 5 & Septa type & 11: pericheatin; 12: lumbricin \\
\hline 6 & Ratio septa between VIII/XXX & $13:>1 ; 14:<1 ; 15:=1$ \\
\hline 7 & Clitellum & 16: annular; 17: saddle-shaped \\
\hline 8 & Number of clitellum segment & 18: 3 segment; 19: 5 segment; 20: segment \\
\hline 9 & The first location of clitellum & 21: in XIII; 22: in XIV; 23 : in XV \\
\hline 10 & Spermathecae & $\begin{array}{l}\text { 24: } 1 \text { segment; } 25: 2 \text { segment; } 26: 3 \\
\text { segment; } 27: 4 \text { segment }\end{array}$ \\
\hline 11 & The first location of spermathecae pore & $28:$ in $5 / 6 ; 29:$ in $6 / 7 ; 30:$ in $7 / 8$ \\
\hline 12 & Number of spermathecae pore in a segment & 31: polytheca; 32: bitheca \\
\hline 13 & Location of spermathecae pore in a segment & 33: ventral; 34: lateral - ventral \\
\hline 14 & Number of female pore & 35: single; 36: pair \\
\hline 15 & Location of male pore & 37: in XVIII; 38: in 19/20 \\
\hline 16 & Types of male pore & 39: type $1 ; 40:$ type $2 ; 41:$ type $3 ; 42:$ type 4 \\
\hline 17 & Genital marking & 43: absent; 44: single; 45: pair \\
\hline 18 & Types of genital gland & 46: absent; 47: type 1; 48: type 2 \\
\hline 19 & External marking & 49: existence; 50: absent \\
\hline 20 & Intestinal caeca & 51: absent; 52: simple \\
\hline 21 & Types of micronephridia & 53: meroic; 54: holoic \\
\hline 22 & Location of diverticulum & $\begin{array}{l}\text { 55: near spermathecae pore; } 56 \text { : origin of } \\
\text { duct of ampulla; } 57 \text { : in duct of ampulla }\end{array}$ \\
\hline 23 & Number of diverticulum in a spermathecae & 58: absent; 59: one \\
\hline 24 & Types of prostate glands & 60: absent; 61: tubular; 62: racemose \\
\hline 25 & Calcium gland & 63: absent; 64: existence \\
\hline 26 & Situation of septa in $8 / 9$ & 65: absent; 66: thickness \\
\hline 27 & Number of testis sacs & 67: 2 pair; $68: 1$ pair \\
\hline 28 & Location of seminal vesicles & 69: in XI and XII; 70: in XIII \\
\hline
\end{tabular}

Whole-cell protein electrophoretic analysis using SDS-PAGE: this method included steps as follows: Extracting proteins: earthworms were weighed promptly after they had been desensitized so as to minimize protein degradation. Five grams of tissues of eachworm 
species were homogenized with previously cooled mortars and pestles in $0.5 \mathrm{ml}$ protein extraction buffer $(0.05 \mathrm{M}$ phosphate buffer, $\mathrm{pH} 7$ $+0.5 \% \mathrm{NaCl}+$ EDTA + $1 \mathrm{mM} \mathrm{PMSF}+5 \mathrm{mM}$ EDTA). The contents were centrifuged at $10 \mathrm{rpm}$ for 10 minutes at $4^{\circ} \mathrm{C}$ and the supernatants were stored at $5^{\circ} \mathrm{C}$. Measuring protein concentration: protein concentration was calibrated by Bradford (1976) method [7]. SDS-PAGE was performed following the Leammil (1970) protocol [16].

DNA barcode analysis: this method included steps as follows: Genomic DNA of earthworms was extracted by following the CTAB procedure [20] with few modifications. DNA barcodes were amplified by Polymerase Chain Reaction using the universal primers LCO1490 and HCO2198 [12]. This pair of primers did not work well for A. paraalexandri and $M$. houlleti and was thus modified slightly by using another pair of primers, for which primer HCO2198 was replaced by primer COIE [8]. PCR products were purified using the PureLink $^{\mathrm{TM}}$ Genomic DNA Mini Kit (Applied Biosystems, CA, USA) following the protocol provided by the manufacturer. Sequencing was performed with the Cycle Sequencing Ready Reaction Kit, V3.1 (Applied Biosystems, CA, USA) on an ABI 3130 Genetic Analyzer following the standard cycle sequencing protocol. Amplified COI fragments were checked with the GeneBank BLASTN 2.2.26+ algorithm to verify that all sequences were from Oligochaeta. The mean interspecific distance as well as interspecific p-distances were calculated in MEGA5. Eight previously sequenced DNA fragments together with 10 additional DNA barcode sequences from 10 different species of three distinct earthworm families retrieved from the GeneBank were used to construct the common phylogenetic tree. Sequences were aligned using Clustal X 1.81. Regions that could not be unambiguously aligned were excluded from analysis. Alignment was improved manually using BIOEDIT 5.0.9.

Phylogenetic construction was performed by applying maximum parsimony (MP) method using PAUP 4.0b10. MP tree with 1000 bootstrap replicates was analyzed by heuristic search with tree-bisection-reconnection (TBR) branch-swapping algorithm implemented in the PAUP program.

\section{RESULTS AND DISCUSSION}

\section{Genetic relationships between earthworm species determined on the basis of morphological characteristics}

The mean interspecific relationship was $26.85 \%$ [sd $=10.22]$, ranging from a low of $7.14 \%$ between $M$. houlleti and Metaphire sp. 8 to a high of $42.86 \%$ between $P$. elongata and Metaphire sp. 8 and between $P$. taprobanae and Metaphire sp.8 (table 1).

The dendrogram constructed from the similarity matrix of 10 taxa showed that 10 species could be grouped into two big groups (figure 1). Group 1: included Pontoscolex corethrurus that belongs to the Glossoscolecidae family with $100 \%$ bootstrap support. Group 2: included 9 taxa that derived from the Megascolecidae family with relative high bootstrap support of $66 \%$. Within the group 2, the Pheretimoid earthworms (indicated in bold) formed a monophyletic sub-group with $100 \%$ bootstrap support that were apart from the branch of Pontodrilus litoralis (group 2C). These earthworms, in turn, can be divided into two sub-groups denoted 2A and 2B. Sub-group 2A included 4 taxa: P. elongata, $P$. taprobanae, M. posthuma and A. paraalexandri while subgroup 2B contained M. bahli, M. peguana, M. houlleti và Metaphire sp.8. The two subgroups have hight bootstrap and the values of that were $82 \%$ and $83 \%$, respectively.

The dendrogram clearly distinguished the genetic relationships between taxa of different families and genera. To be more specific, the dendrogram appropriately showed that species of the genus Pheretima in $2 \mathrm{~A}$ and $2 \mathrm{~B}$ subgroups had closer relationships than those of Pontodrilus litoralis that belongs to the genus Pontodrilus (group 2C). All species of Megascolecidae (2A, 2B and 2C) showed less genetic divergence compared with Pontoscolex corethrurus (group 1) of the Glossoscolecidae family. Moreover, the topology of this dendrogram also gave a nice description of evolutionary divergence between earthworms 
belonging to the Pheretima species group. In more detail, 6 species of the Pheretimoid earthworms were divided into three pairs of taxa in the dendrogram: $M$. bahli and M. Peguana; $M$. houlleti and Metaphire sp.8; P. elongata and P. taprobanae.

Table 1. Genetic relationship between 8 species based on morphological traits

\begin{tabular}{|l|c|c|c|c|c|c|c|c|}
\hline \multicolumn{1}{|c|}{ Species } & {$[1]$} & {$[2]$} & {$[3]$} & {$[4]$} & {$[5]$} & {$[6]$} & {$[7]$} & {$[8]$} \\
\hline [1] Metaphire bahli & - & & & & & & & \\
\hline [2] Metaphire peguana & 10.71 & - & & & & & & \\
\hline [3] Metaphire houlleti & 25.00 & 14.29 & - & & & & & \\
\hline [4] Metaphire sp.8 & 28.57 & 17.86 & 7.14 & - & & & & \\
\hline [5] Metaphire posthuma & 32.14 & 28.57 & 32.14 & 39.29 & - & & & \\
\hline [6] Amynthas paraalexandri & 32.14 & 25.00 & 28.57 & 35.71 & 25.00 & - & & \\
\hline [7] Polypheretima elongata & 32.14 & 32.14 & 35.71 & 42.86 & 17.86 & 28.57 & - & \\
\hline [8]Polypheretima taprobanae & 32.14 & 32.14 & 35.71 & 42.86 & 25.00 & 21.43 & 17.86 & - \\
\hline
\end{tabular}

Interspecific relationship (given in percentage) for 8 earthworm species were calculated by NTSYS-PC 2.1 using Dice's coefficient.

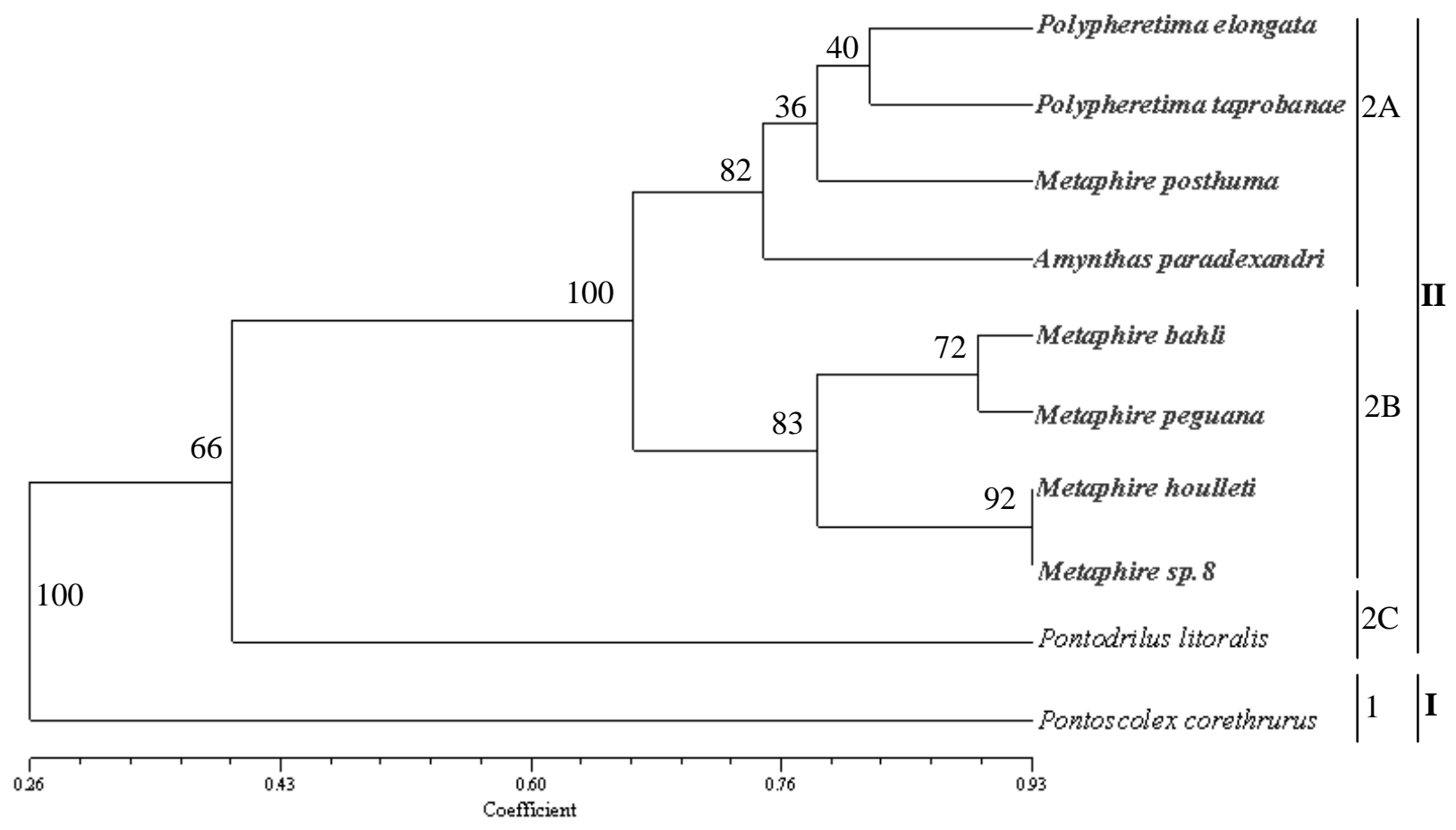

Figure 1. A dendrogram generated using UPGMA method with arithmetic average analysis of 10 taxa based on the analysis of morphological traits

The numbers at the nodes indicate the confidence limits for the grouping of those species in a branch based on 1,000 cycles in bootstraps analysis using the FreeTree program. I. Glossoscolecidae; II. Megascolecidae.

The above results were highly consistent with the current perspectives on morphological taxonomy but were not without some inconsistency. According to Sims and Easton (1972) [18], the Pheretima species group that had the intestinal caeca were divided into smaller genera including Metaphire, Amynthas, Pithema and Pheretima. Nevertheless, the dendrogram in figure 1 and table 1 showed that A. paraalexandri had closer relationship with 
M. posthuma and M. peguana (genetic distance were $25 \%$ ) than with other species belonging the genus Metaphire (e.g. Genetic distance between $M$. posthuma and $M$. houlleti was $39.29 \%$ ). Some previous research on molecular analyses also gave similar results [10]. According to Easton (1979) [11], the Pheretima species group that was acoecata evolved faster compared to coecata and diverged in another evolutionary direction. Nevertheless, the dendrogram showed that M. posthuma had closer relationships with $P$. elongata and $P$. taprobanae (did not have the intestinal caeca) (genetics distances ranged from $17.8 \%$ to $25 \%)$ than with other species that had the intestinal caeca (28.57\% to $39.29 \%)$.

Genetic relationships between earthworm species determined on the basis of whole-cell protein electrophoretic analysis using SDSPAGE

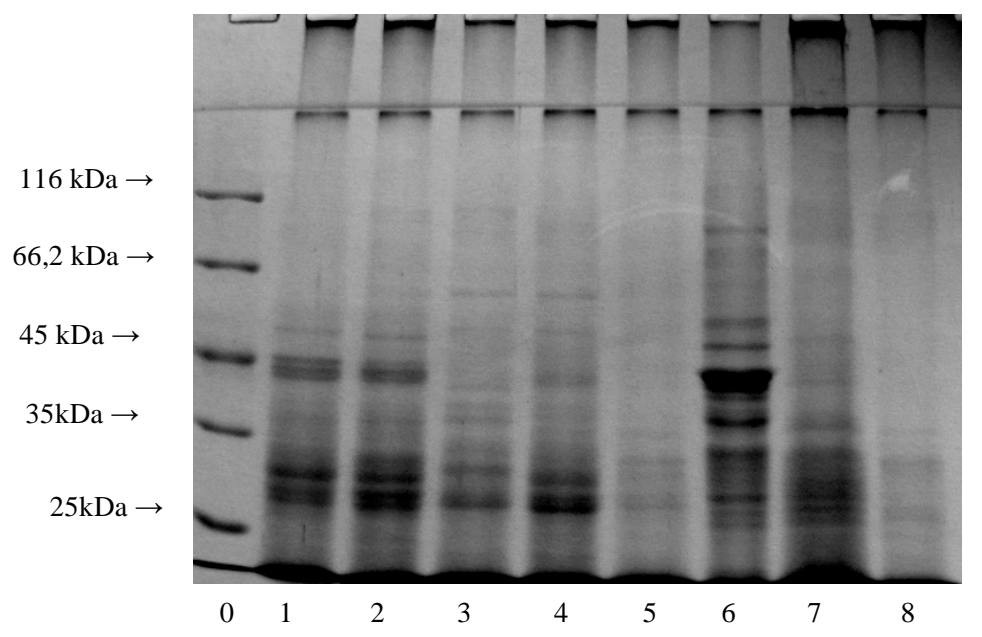

Figure 2. Electrophoretic patterns of the whole-cell proteins of eight earthworm species belonging to the Pheretima species group in the Me Kong delta

0. protein ladder; 1. M. houlleti; 2. Metaphire sp.8; 3. M. bahli; 4. M. peguana; 5. P. elongata; 6. P. taprobanea; 7. M. posthuma; 8. A. juliani.

Interspecific p-distances were calculated by NTSYS-PC 2.1 based on the electrophoretic pattterus of the whole-cell proteins of 8 species (figure 2). The mean interspecific distance was $36.66 \%(\mathrm{SD}=14.53 \%)$, which was $8.86 \%$ higher than that calculated based on morphology $(\mathrm{SD}=8.98)$. These distances ranged from a high of $92,68 \%(100 \%-7.32 \%)$ between $M$. posthuma and A. juliani to a low of $38,89 \%(100 \%-61.11 \%)$ between $M$. houlleti and $M$. bahli (table 2).

The topology of the phylogenetic tree based on banding patterns of the whole-cell proteins showed that investigated earthworms could be divided in two big groups with the bootstrap support of $100 \%$. Group 1: consisted of 4 species: M. houlleti, Metaphire sp.8, M. posthuma and $A$. juliani, while group 2 contained 4 species:
M. bahli, $M$. peguana, $P$. elongata and $P$. taprobanea. These two groups did not represent any taxonomic unit. This tree also clearly exhibited the genetic diversity between earthworm species in the species group as shown by relationship between $M$. houlleti and Metaphire sp. 8 (genetic similarities of $11.11 \%$, bootstrap support of 85\%); M. posthuma and A. juliani (genetic similarities of $7.32 \%$, bootstrap support of 93\%); M. bahli and $M$. peguana (genetic similarities of $10.53 \%$, bootstrap support of 96\%). Both dendrograms (based on morphological traits and whole-cell protein patterns) did not show clearly the division between species groups that did not have the intestinal caeca ( $P$. elongata, $P$. taprobanea) and those that had the intestinal caeca (remaining species). 
Table 2. Genetic relationship between 8 species based on whole-cell protein electrophoretic analysis using SDS-PAGE

\begin{tabular}{|l|c|c|c|c|c|c|c|c|}
\hline \multicolumn{1}{|c|}{ Species } & {$[1]$} & {$[2]$} & {$[3]$} & {$[4]$} & {$[5]$} & {$[6]$} & {$[7]$} & {$[8]$} \\
\hline [1] Metaphire bahli & - & & & & & & & \\
\hline [2] Metaphire peguana & 10.53 & - & & & & & & \\
\hline [3] Metaphire houlleti & 61.11 & 50.00 & - & & & & & \\
\hline [4] Metaphire sp. 8 & 52.63 & 42.11 & 11.11 & - & & & & \\
\hline [5] Metaphire posthuma & 58.97 & 48.72 & 18.92 & 23.08 & - & & & \\
\hline [6] Amynthas juliani & 50.00 & 40.00 & 21.05 & 25.00 & 7.32 & - & & \\
\hline [7] Polypheretima elongata & 31.58 & 26.32 & 44.44 & 36.84 & 38.46 & 40.00 & - & \\
\hline [8] Polypheretima taprobanae & 39.54 & 34.88 & 51.22 & 53.49 & 36.36 & 33.33 & 39.54 & - \\
\hline
\end{tabular}

Notes: Interspecific p-distances (given in percentage) for 8 earthworm species were calculated by NTSYS-PC 2.1 using Dice's coefficient.

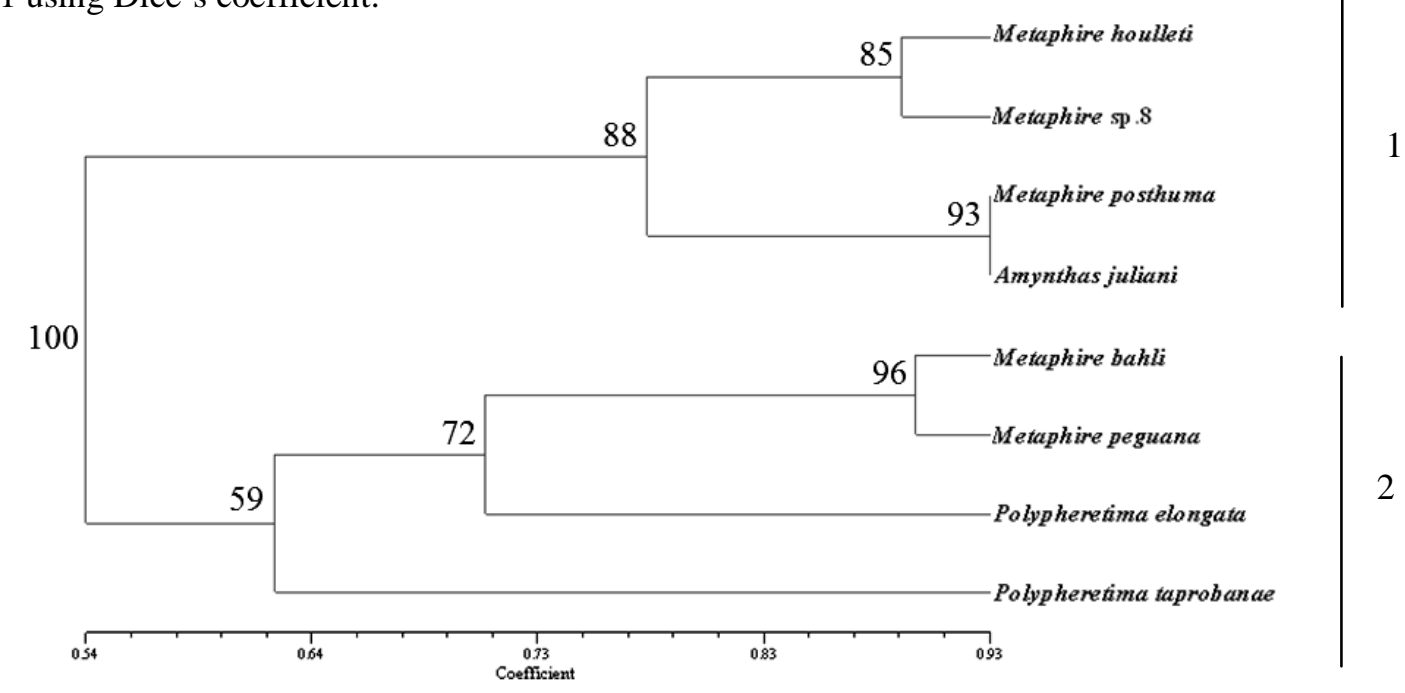

Figure 3. A dendrogram generated using UPGMA method with arithmetic average analysis of 8 taxa based on the analysis of proteins banding patterns

The numbers at the nodes indicate the confidence limits for the grouping of those species in a branch based on 1,000 cycles in bootstraps analysis using the FreeTree program.

Genetic relationships between earthworm species determined on the basis of DNA barcodes analysis

The mean interspecific relationship calculated based on the data of DNA barcodes was $16.99 \%$ ranging from a low of $14.32 \%$ between $P$. elongata and $P$. taprobanae to a high of $19.79 \%$ between $M$. bahli and A. paraalexandri (table 3 ). This was $10.81 \%$ and $19.67 \%$ lower than that previously calculated mean of interspecific relationship based on the similarity matrix of morphology and protein banding patterns, respectively. Genetic relationship between species calculated based on DNA barcodes data $(\mathrm{sd}=1.32)$ were less variable than those calculated using the data morphological (10.22) and protein electrophoretic analyses (14.53).

In this study, result based on morphological and protein electrophoretic analyses showed that Metaphire sp. 8 and M. houlleti had low genetic similarities $(7.14 \%$ and $11.11 \%$, respectively). By contrast, this value increased to $15.68 \%$, being higher than the genetic similarities between two closely related species $M$. peguana and M. bahli (14.61\%) and between two species that did not have the intestinal caeca $(14.32 \%)$. This demonstrated that Metaphire sp. 8 is a probably new species that has a close relationship with M. houlleti. 
Table 3. Genetic relationship between 8 species based on DNA barcodes anaylysis

\begin{tabular}{|l|c|c|c|c|c|c|c|c|}
\hline Species & {$[1]$} & {$[2]$} & {$[3]$} & {$[4]$} & {$[5]$} & {$[6]$} & {$[7]$} & {$[8]$} \\
\hline [1] Metaphire bahli & - & & & & & & & \\
\hline [2] Metaphire peguana & 14.61 & - & & & & & & \\
\hline [3] Metaphire houlleti & 17.35 & 17.35 & - & & & & & \\
\hline [4] Metaphire sp.8 & 17.66 & 16.89 & 15.68 & - & & & & \\
\hline [5] Metaphire posthuma & 18.42 & 15.22 & 16.89 & 17.50 & - & & & \\
\hline [6] Amynthas paraalexandri & 19.79 & 18.42 & 18.87 & 16.89 & 17.66 & - & & \\
\hline [7] Polypheretima elongata & 15.07 & 15.83 & 16.13 & 16.44 & 15.83 & 18.11 & - & \\
\hline [8] Polypheretima taprobanae & 17.96 & 17.96 & 17.20 & 17.96 & 16.13 & 17.50 & 14.32 & - \\
\hline
\end{tabular}

Interspecific relationship (given in percentage) for the 8 species were calculated in MEGA5.

In studies previously published in Vietnam, Metaphire sp. 8 were identified as Pheretima campanulata [2] but Rosa (the author published this species) suggested that it was the synonym of M. houlleti [5].

The topology of the cladogram showed three distinct clades with variable bootstrap support (figure 4). Clade 1 had only one Pontoscolex corethrurus species with $68 \%$ bootstrap support and this is reasonable as this species belongs to the other earthworm family (Glossoscolecidae). This agreed with the dendrogram construction based on morphology and current perspectives on the classification of earthworms. Clade 2 was the largest and most apical clade that consisted of all 15 taxa of the Megascolecidae family with relatively high bootstrap support of 50\%. Clade 3 consisted of two species of Eisenia fetida and Lumbricus terrestris of the Lumbricidae family with high bootstrap support of $83 \%$.

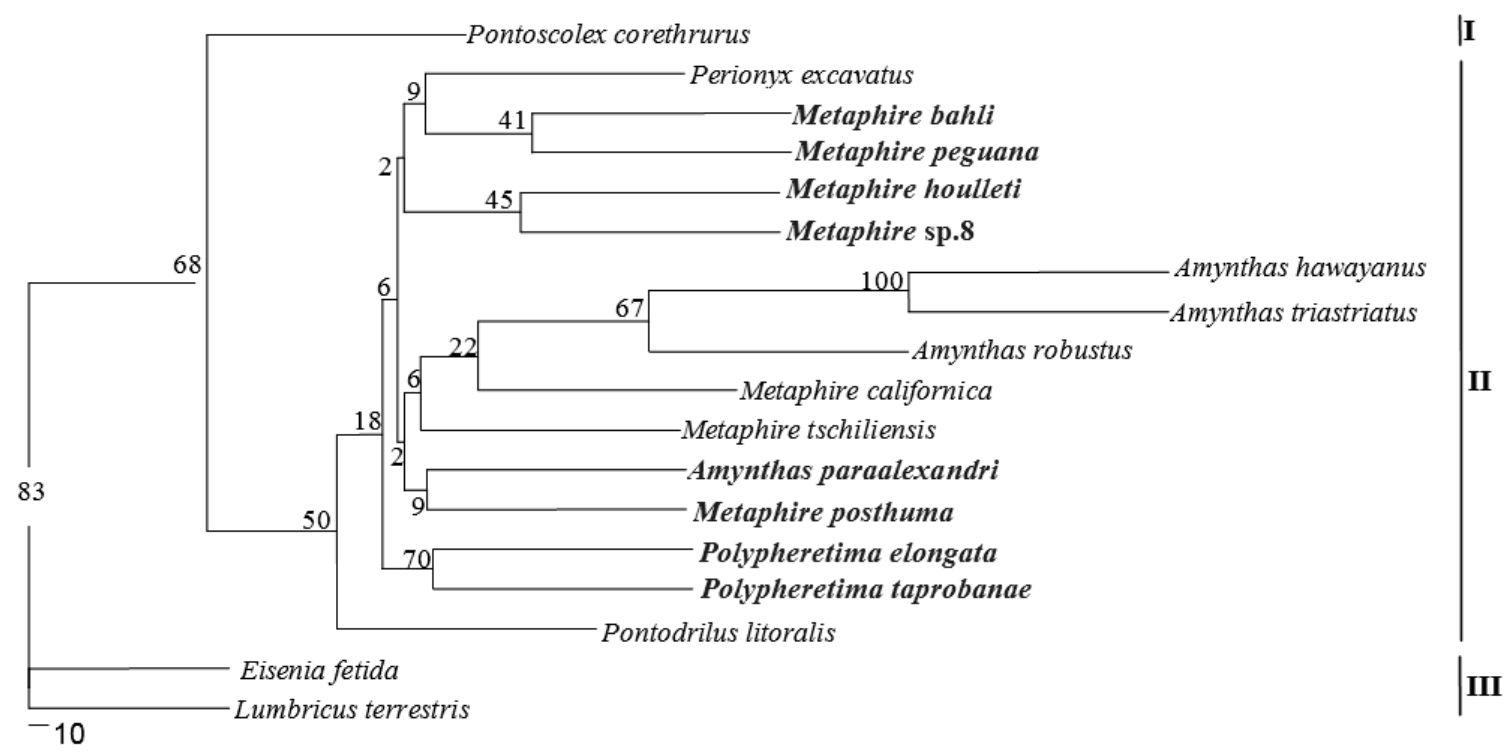

Figure 4. Maximum parsimony analysis of a $639 \mathrm{bp}$ fragment of the COI gene after combination of partial COI sequences from the GeneBank

Numbers at nodes indicated bootstrap values from 1000 replicates. I. Glossoscolecidae; II. Megascolecidae; III. Lumbricidae.

Within clade II, Pontodrilus litoralis was separated from the other species with the bootstrap support of $50 \%$. This is similar with many previous research of taxonomic position for this species. The genus Pontodrilus was categorized as a member of the Acanthodrilidae, however the 
data on molecular biology that have been published recently showed that Pontodrilus litoralis had a closer relationship with other species of Megascolecidae than those of Acanthodrilidae [6]. Although Perionyx excavatus belongs to a distinct genus but it has not been separated from Pheretima species group yet.

In addition, the maximum parsimony tree based on DNA barcodes data clearly exhibited the evolutionary divergence between the Pheretimoid earthworms that are coecata (Amynthas and Metaphire species) and acoecata (P. elongata and P. taprobanae), when the later group evolved earlier and separated from the others on the cladogram with the bootstrap support of $70 \%$. This pattern was not recognized in the dendrograms constructed based on morphological and protein eletrophoretic analysis. Besides, the species of the genus Amynthas including A. hawayanus, A. triastriatus và $A$. robustus formed a monophyletic group with the bootstrap support of $67 \%$ except $A$. paraalexandri which was outside this group. This is similar with other studies when the clear distinction of species division of Amynthas and Metaphire was not observed all the time [15].

\section{CONCLUSIONS}

All of three methods: morphological, the whole-cell protein electrophoretic and DNA barcode analyses yielded compatible and reliable results which appropriately explained the genetic relationships between closely related species in the Pheretima species group.

Phylogenetic trees constructed on the basis of morphological and DNA barcode analysis clearly exhibited genetic relationships at different taxonomic levels (families and genera) (except Perionyx excavatus).

Relationships between the species of the Pheretimoid earthworms that have and do not have the intestinal caeca were exclusively shown on the phylogenetic tree constructed based on DNA barcodes analysis.

Phylogenetic trees constructed based on morphological and protein electrophoretic analyses did not show the differentiation of the species of Amynthas and Metaphire into two groups, while the tree based on DNA barcode analysis showed the trend of separation but not very clear in all species.

Metaphire sp. 8 is a closely related species with $M$. houlleti.

\section{REFERENCES}

1. Thái Trần Bái, 1986. Khóa định loại các loài giun đất ở đồng bằng sông Hồng và đồng bằng sông Cửu Long Việt Nam. Đại học Sư phạm Hà Nội: 3-20.

2. Thái Trần Bái, 2000. Đa dạng loài giun đất ở Việt Nam. Những vấn đề nghiên cứu cơ bản trong sinh học. Đại học quốc gia Hà Nội: 307-311.

3. Trần Thị Thanh Bình, Đặng Tất Thế, 2006. Dẫn liệu DNA của hai loài giun đất Pheretima aspergillum và Pheretima robusta. Tạp chí Khoa học, đại học Sư phạm Hà Nội, 4: 130-135.

4. Apuan D. A., Anthony M., Torres J. and Demayo C. G., 2010. Describing variations and taxonomic status of earthworms collected from selected areas in Misamis Oriental, Philippines using principal component and parsimony analysis. Egypt. Acad. J. Biol. Sci., 2(1): 27-36.

5. Beddard F. E., 1895. A Monograph of the Order of Oligochaeta. Oxford, Clarendon Press: 424-426.

6. Blakemore R. J., 2007. Origin and means of dispersal of cosmopolitan Pontodrilus litoralis (Oligochaeta: Megascolecidae). Eur. J. Soil. Biol., 43: S3-S8.

7. Bradford M. M., 1976. A rapid and sensitive for the quantitation of microgram quantitites of protein utilizing the principle of protein-dye binding. Anal. Biochem., 72: 248-254.

8. Bely A. E. and Wray G. A., 2004. Molecular phylogeny of naidid worms (Annelida; Clitellata) based on cytochrome c oxidase I. Mol. Phylogenet Evol., 30: 50-63.

9. Chang C. H. and Chen J. H., 2005. Taxonomic status and intraspecific phylogeography of two sibling species of 
Metaphire (Oligochaeta: Megascolecidae) in Taiwan. Pedobiol., 49: 591-600.

10. Chang C. H., Lin S. M. and Chen J. H., 2008. Molecular systematics and phylogeography of the gigantic earthworms of the Pheretima formosae species group (Clitellata, Megascolecidae). Mol. Phylogenet Evol., 49(3): 958-968.

11. Easton E. G., 1979. A revision of the 'acaecate' earthworms of the Pheretima group (Megascolecidae: Oligochaeta): Archipheretima, Metapheretima, Planapheretima, Pleionogaster and Polypheretima. Bull. Br. Mus. Nat. Hist. (Zool.), 35: 1-126.

12. Folmer O., Black M., Hoeh W., Lutz R. and Vrijenhoek R., 1994. DNA primers for amplification of mitochondrial cytochrome c oxidase subunit I from diverse metazoan invertebrates. Mol. Mar. Biol. Biotechnol, 3: 294-299.

13. Ishizuka K., 1999. A review of the genus Pheretimas. lat. (Megascolecidae) from Japan Edaphol., 62: 55-80.
14. Jamieson B. G. M., 1988. On the phylogeny and higher classification of the Oligochaeta. Cladistics, 4: 367-410.

15. Huang J., Xu Q., Sun Z. J., Tang G. L. and Su Z. Y., 2007. Identifying earthworms through DNA barcodes. Pedobiol., 51(4): 301-309.

16. Laemmli U. K., 1970. Cleavage of structural proteins during the assembly of the head of bacteriophage T4. Nature, 227(5259): 680-685.

17. Rogers S. O. and Bendich A. J. B., 1988. Extraction of DNA from plant tissues. Plant molecular Biology Manual. Klurwer Academic Publishers, Dordrecht, Belgium: $1-10$.

18. Sims R. W. and Easton E. G., 1972. A numerical revision of the earthworm genus Pheretima auct. (Megascolecidae: Oligochaeta) with the recognition of new genera and an appendix on the earthworms collected by the Royal Society North Borneo Expedition. Biol. J. Lin. Soc., 4: 169-268.

\title{
THỬ NGHIÊM 3 PHƯƠNG PHÁP XÁC ĐINH MỐI QUAN HÊ ĐA DANG DI TRUYỀN TRÊN MỘT SỐ LOÀI GIUN ĐẤT THUỘC NHÓM LOÀI PHERETIMA Ở ĐỒNG BẰNG SÔNG CỦU LONG
}

\author{
Nguyễn Thanh Tùng, Trần Nhân Dũng, Phạm Minh Tú \\ Trường đại học Cần Thơ
}

\section{TÓM TẮT}

Bài báo này giới thiệu kết quả thử nghiệm 3 phương pháp (phân tích dựa trên cơ sở hình thái học, điện di protein SDS - PAGE, giải trình tự mã vạch DNA Barcode) để xác định mối quan hệ đa dạng di truyền ở một số loài giun đất thuộc nhóm Pheretima ở đồng bằng sông Cửu Long (Amynthas paraalexandri, A. juliani, Metaphire posthuma, M. bahli, M. peguana, M. houlleti, Metaphire sp.8, P. elongata và $P$. taprobanae). Cả 3 phương pháp đều cho kết quả tương thích, chính xác để giải thích mối quan hệ giữa các loài trong nhóm loài gần gũi và giữa tác taxon bậc cao (họ, giống). Mối quan hệ giữa 2 nhóm Pheretima không có manh tràng và có manh tràng chỉ được thể hiện rõ khi xây dựng sơ đồ phả hệ dựa trên trình tự DNA Barcode. Mối quan hệ giữa các loài trong giống Amynthas và Metaphire chưa thể hiện rõ ở phương pháp hiện trạng số và điện di protein SDS-PAGE, có xu hướng rõ hơn khi so sánh trình tự DNA barcode. Từ kết quả nghiên cứu cũng đã chứng minh được Metaphire sp.8 là 1 loài gần gũi với M. houlleti.

Tù khóa: Pheretima, đa dạng di truyền, giun đất, hình thái học, mã vạch DNA, SDS-PAGE đồng bằng sông Cửu Long.

Ngày nhận bài: 30-8-2010 